\title{
The Risk Assessment of Sediment Heavy Metal Pollution in the East Dongting Lake Wetland
}

\author{
Cong Hu, ${ }^{1,2,3}$ Zheng-miao Deng, ${ }^{1,2}$ Yong-hong Xie, ${ }^{1,2}$ Xin-sheng Chen, ${ }^{1,2}$ and Feng $\mathrm{Li}^{1,2}$ \\ ${ }^{1}$ Key Laboratory of Agroecological Processes in Subtropical Region, The Chinese Academy of Sciences, Changsha 410125, China \\ ${ }^{2}$ Dongting Lake Station for Wetland Ecosystem Research, Institute of Subtropical Agriculture, The Chinese Academy of Sciences, \\ Changsha 410125, China \\ ${ }^{3}$ University of Chinese Academy of Sciences, Beijing 100049, China
}

Correspondence should be addressed to Yong-hong Xie; yonghongxie@163.com

Received 4 September 2014; Revised 7 January 2015; Accepted 11 January 2015

Academic Editor: Yongjun Gao

Copyright (C) 2015 Cong Hu et al. This is an open access article distributed under the Creative Commons Attribution License, which permits unrestricted use, distribution, and reproduction in any medium, provided the original work is properly cited.

Total concentrations of cadmium $(\mathrm{Cd})$, lead $(\mathrm{Pb})$, chrome $(\mathrm{Cr})$, and nickel $(\mathrm{Ni})$ in surface sediment $(0-10 \mathrm{~cm})$ from the East Dongting Lake wetlands were determined and the spatial distribution of heavy metals was mapped. The results showed that the single risk indices $\left(E_{r}^{i}\right)$ of heavy metals were ranked in the order of $\mathrm{Cd}>\mathrm{Pb}>\mathrm{Ni}>\mathrm{Cr}$. The content of $\mathrm{Cd}$ and $\mathrm{Pb}$ was gradually reduced from the east (Xiangjiang River) to the west, while the $\mathrm{Cr}$ and $\mathrm{Ni}$ content had a patchy distribution pattern in the East Dongting Lake wetlands. $\mathrm{Cd}$ and $\mathrm{Pb}$ contents were correlated with soil $\mathrm{pH}$ significantly, while $\mathrm{Cr}$ and $\mathrm{Ni}$ contents were correlated with soil organic carbon (SOC) and total nitrogen (TN). The origination of heavy metal $(\mathrm{Cd}, \mathrm{Cr}, \mathrm{Ni}$, and $\mathrm{Pb}$ ) could be divided into two groups: $\mathrm{Cd}$ and $\mathrm{Pb}$ from anthropogenic source and $\mathrm{Cr}$ and $\mathrm{Ni}$ from parent material weathering. Our results indicated that $\mathrm{Cd}$ posed a high risk to local ecosystem. The relatively lower $\mathrm{pH}$ and higher soil organic carbon (SOC) and total nitrogen (TN) in sediment may inhibit the fixation of heavy metals, which in turn increased the concentration of heavy metal in sediment.

\section{Introduction}

Heavy metals such as cadmium (Cd), chromium (Cr), nickel $(\mathrm{Ni})$, and lead $(\mathrm{Pb})$ are the common metal pollution that was found in farmland [1], tidal freshwater and marshes [2], and aquatic and wetland systems [3]. Because of adsorption, hydrolysis, and coprecipitation, only a small portion of free metal ions could be taken away by water flows (e.g., flooding or rainfall runoff) and a large quantity of them get deposited in the sediment [4], which endangered human health by food cycle [5]. Wetlands and aquatic systems might be more easily polluted by heavy metals due to the industrial, agricultural, municipal, and residential waste water discharging [6]. Therefore, the risk assessment of heavy metal pollution from wetlands and aquatic systems has attracted more attention in recent years.

The availability of heavy metals in sediment is largely affected by the sediment properties and hydrological conditions in wetlands, and the toxicity of heavy metals also depends on factors such as concentration, speciation, and bioavailability [7]. Soil organic matter (SOM) can act as a major sink for trace elements due to its strong capacity for complexing metallic contaminants [2], and $\mathrm{pH}$ is usually negatively correlated with metal pollution such as $\mathrm{Cr}$ and $\mathrm{Pb}$ in paddy soils [8]. Additionally, Kumpiene et al. (2008) demonstrated that the variation in hydrological conditions and soil physicochemical properties could change the fixation, mobility, and bioavailability of heavy metals in sediment [9]. Du Laing et al. (2009) also reported that metal contents were significantly correlated with salinity, clay, and organic matter contents in estuarine and riparian floodplain sediment [10]. Factually, bottom lake sediments are not only the sink for heavy metals, but also the potential secondary sources of heavy metals in aquatic systems [11]. It is therefore important to understand the spatial distribution, the spatial ecological risk status, and the priority sources of heavy metals in sediments in order to develop strategies and approaches for efficient pollution control. 
Dongting Lake, which includes three national wetland nature reserves, namely, the East Dongting Lake, the South Dongting Lake, and the West Dongting Lake, is the second largest freshwater lake in China. The East Dongting Lake, which covers an area of $1,328 \mathrm{~km}^{2}$, is the biggest part of Dongting Lake. Vegetation in the East Dongting Lake wetlands has developed well on the sandbars and provides a rich food supply and shelter for wildlife, especially for many migratory birds. Xiangjiang watershed, which is one of the main inflows of the East Dongting Lake, has been subjected to serious pollution due to emissions of $\mathrm{Cd}, \mathrm{Cr}, \mathrm{Ni}$, and $\mathrm{Pb}$ by the metallurgical industry [12-14]. It reported that the potential ecological risk of heavy metal pollution (especially for $\mathrm{Cd}$ ) is the highest in the sediment of East Dongting Lake [15].

In this study, the spatial distribution and ecological risk assessment of heavy metals $(\mathrm{Cd}, \mathrm{Cr}, \mathrm{Ni}$, and $\mathrm{Pb}$ ) pollution in sediment were studied in the East Dongting Lake to meet the following objectives: (1) to investigate spatial distributions of studied heavy metal contents in surface sediment from the East Dongting Lake based on a geostatistics method (the kriging interpolation), (2) to map spatial potential ecological risk posed by studied heavy metals through calculating the Hakanson potential ecological risk index, and (3) to separate the natural and/or anthropogenic sources of these heavy metals by using combined multivariate statistical techniques including principal component analysis (PCA).

\section{Materials and Methods}

2.1. Study Area. The East Dongting Lake $\left(28^{\circ} 28^{\prime}-29^{\circ} 35^{\prime} \mathrm{N}\right.$, $\left.112^{\circ} 19^{\prime}-113^{\circ} 05^{\prime} \mathrm{E}\right)$ locates the northeast of Hunan Provinces in the middle China. The climate of this area is a continental subtropical monsoon humid climate. The average annual rainfall is $1200-1300 \mathrm{~mm}$ and annual frost-free period is 285 days. As it connects to the Yangtze River, the lake's size varies greatly from season to season. During a year, the water level in Dongting Lake varies apparently; it may rise by as much as 16 meters. The water level increases in April and the highest level appears between June and August. Then, the water level begins to descend in September and the lowest one comes from December to March in the next year. It plays a key role not only in storing floodwater, agricultural irrigation, water supply, and climatic regulation, but also in producing a good deal of freshwater fish and the habitat for migrant birds.

2.2. Sampling Method. The sediment samples were collected during December 12-25, 2013. Before sampling, the sampling sites were selected on the map of East Dongting Lake using a systematic grid sampling method [16]. The initial point of the grid was randomly selected and $2 \mathrm{~km}$ apart from each other. However, because of the human activities (i.e., fish culture and ditching), a small part of sampling sites was lacked and finally, a total of 174 sampling sites were established in our field investigation (Figure 1). The sampling locations (latitudinal and longitudinal position) were recorded by a hand-held global positioning system (GPS) unit. At each sampling site, a quadrat $(1 \mathrm{~m} \times 1 \mathrm{~m})$ was randomly set firstly and five subsamples (from the upper $0-10 \mathrm{~cm}$ depth of sediment) were collected from the center and four corners of the quadrat using a wooden shovel. Then, the completed mixing sediment samples were put into a sealed polyethylene bag and transported to the laboratory for storage at $-20^{\circ} \mathrm{C}$. In addition, another sediment sample was collected from $0-10 \mathrm{~cm}$ belowground using a cutting ring for measuring sediment moisture and bulk density.

For the purposes of determining sediment chemical properties, all sediment samples were air-dried at room temperature and sieved through a $2 \mathrm{~mm}$ nylon sieve to remove coarse debris. Some the air-dried sediment samples (ca. $100 \mathrm{~g}$ ) were then grounded with a pestle and mortar until all particles passed a $0.149 \mathrm{~mm}$ nylon sieve for total heavy metal concentration analysis [17].

Sediment samples were digested by $\mathrm{HClO}_{4}-\mathrm{HNO}_{3}-\mathrm{HF}$ mixture in Teflon tubes at $160^{\circ} \mathrm{C}$ for $6 \mathrm{~h}$ in an oven. The solution was heated up until the acid was reduced to a volume of $1-2 \mathrm{~mL}$ and then made up to a volume of $10 \mathrm{~mL}$ with $1 \%$ $\mathrm{HNO}_{3}$. The solution of the digested samples was analyzed by inductively coupled plasma atomic absorption spectrometry (ICP/AES) for $\mathrm{Cd}, \mathrm{Cr}, \mathrm{Ni}$, and $\mathrm{Pb}$. Quality assurance and quality control were assessed using duplicates, blank samples, and standard reference materials (GBW07401, obtained from Chinese Academy of Measurement Sciences) with each batch of samples (1 blank and standard for each 10 samples) [18]. The remaining sediment samples were powdered through a $0.25 \mathrm{~mm}$ nylon sieve to measure soil organic carbon (SOC), total nitrogen (TN), and total phosphorous (TP) and through a $0.85 \mathrm{~mm}$ nylon sieve to measure $\mathrm{pH}$. SOC and TN in the filtrates were determined by Vario MAX C-N Elementar Analyzer (Germany). TP was measured using the molybdenum blue method [19]. Sediment $\mathrm{pH}$ was measured using a $\mathrm{pH}$ meter (Hach Company, Loveland, Co, USA) (soil: water = $1: 5)$. The sediment in cutting rings was over dried at $105^{\circ} \mathrm{C}$ for $24 \mathrm{~h}$ and weighed for bulk density and moisture. The sediment properties in the East Dongting Lake wetland were demonstrated in Table 1.

2.3. Potential Ecological Risk Index (RI). To further screen sediment contamination degree caused by heavy metals, potential ecological risk index (RI), which was developed based on sedimentary theory, was introduced to assess the ecological risk degree of heavy metals in the present sediments. Potential ecological risk index was originally proposed by Hakanson (1980) and had been widely used in sediment heavy metal pollution assessment $[20,21]$. The value of RI can be calculated by the following formulas:

$$
\begin{gathered}
C_{f}^{i}=\frac{C_{R}^{i}}{C_{B}^{i}}, \\
E_{r}^{i}=T_{r}^{i} \times C_{f}^{i}, \\
\mathrm{RI}=\sum_{i=1}^{m} E_{r}^{i},
\end{gathered}
$$

where $\mathrm{RI}$ is the sum of the potential risks of individual heavy metal, $E_{r}^{i}$ is the potential risk of individual heavy metal, $T_{r}^{i}$ 
TABLE 1: Descriptive statistics of sediment properties in the East Dongting Lake wetlands. The data represents means \pm S.E. $(N=174)$.

\begin{tabular}{ccccccc}
\hline & Moisture (\%) & Bulk density $\left(\mathrm{g} \mathrm{cm}^{-3}\right)$ & $\mathrm{pH}$ & SOC (\%) & TN (\%) & TP (\%) \\
\hline Sediment & $43.24 \pm 1.80$ & $1.13 \pm 0.02$ & $7.38 \pm 0.08$ & $2.53 \pm 0.12$ & $0.20 \pm 0.01$ & $0.11 \pm 0.01$ \\
\hline
\end{tabular}

TABLE 2: Heavy metal concentration in the sediment of the East Dongting Lake wetlands, geochemistry background of Dongting Lake, and Chinese environmental quality standard for soils.

\begin{tabular}{lcccc}
\hline & $\mathrm{Cd}$ & $\mathrm{Cr}$ & $\mathrm{Ni}$ & $\mathrm{Pb}$ \\
\hline Sediment $\left(\mathrm{mg} \mathrm{kg}^{-1}\right)$ & $1.71 \pm 0.10$ & $108.43 \pm 1.68$ & $46.36 \pm 0.74$ & 41.86 \\
Background value $\left(\mathrm{mg} \mathrm{kg}^{-1}\right)$ & 0.23 & 83.92 & & $41.70 \pm 1.66$ \\
National standards & & & 40 & 27.75 \\
$\quad$ Class I $\left(\mathrm{mg} \mathrm{kg}^{-1}\right)$ & 0.2 & 30 & 60 & 35 \\
Class II $\left(\mathrm{mg} \mathrm{kg}^{-1}\right)$ & 0.6 & 400 & 200 & 350 \\
Class III $\left(\mathrm{mg} \mathrm{kg}^{-1}\right)$ & 1 & & 500 \\
\hline
\end{tabular}

is the toxic-response factor for a given heavy metal, $C_{f}^{i}$ is the contamination factor, $C_{R}^{i}$ is the present concentration of heavy metals in sediments, and $C_{B}^{i}$ is the preindustrial record of heavy metal concentration in sediments. RI is the integrated Hakanson potential ecological risk index for the multiple metals. The following criterion was suggested based on the RI value: $\mathrm{RI} \leq 150$, low potential ecological risk; $150<$ $\mathrm{RI} \leq 300$, moderate potential ecological risk; $300<\mathrm{RI} \leq 600$, considerable potential ecological risk; and RI > 600, high potential ecological risk [21].

2.4. Statistical Analysis. Data analysis was carried out using IBM-SPSS Statistics 21.0 for Windows (IBM Inc., USA). Correlation analysis combined with principal component analysis (PCA) was performed to identify the relationships between the concentrations of heavy metal and soil properties in sediment. The main influencing factors of heavy metal distribution were identified by PCA method with Canoco 4.5 for windows. Because the factor analysis technique allows a considerable reduction in the number of variables and the detection of the structure of the relationships between metals, it has been considered an effective tool for the identification of heavy metal sources $[2,22,23]$. Factor analysis was performed to identify the sources of various heavy metals by evaluating the principal components and computing the eigenvectors of heavy metals in all sediment samples. Only the eigenvalues higher than 1 (Kaiser Criterion) and giving a cumulative variance above $85 \%$ were retained. The principal components were then rotated using the Varimax normalized method.

\section{Results}

3.1. Heavy Metal Concentration in Sediment. The mean value of heavy metals in sediment exceeded the geochemistry background value of Dongting Lake (Table 2). From the Chinese Environmental Quality Standard for sediment, the $\mathrm{Cd}$ concentration exceeded the content of class three and $\mathrm{Cr}$, $\mathrm{Ni}$, and $\mathrm{Pb}$ concentrations ranged between class one and class two. These results indicated that the sediment of the East
Dongting Lake was suffering $\mathrm{Cd}, \mathrm{Cr}, \mathrm{Ni}$, and $\mathrm{Pb}$ pollution and that $\mathrm{Cd}$ pollution was the most serious pollution.

3.2. Relationship between Soil Properties and Heavy Metal Concentration. Pearson's correlation analysis showed that $\mathrm{Cd}$ and $\mathrm{Pb}$ contents were significantly related to $\mathrm{pH}(P<$ 0.01 , Table 3 ), while $\mathrm{Cr}$ and $\mathrm{Ni}$ contents were significantly related to soil organic carbon (SOC) and total nitrogen (TN) $(P<0.01$, Table 3$)$. PCA analysis also showed a significant relationship between sediment properties and heavy metal concentration (Figure 2). $\mathrm{Cd}$ and $\mathrm{Pb}$ contents were negatively correlated with $\mathrm{pH}$, while $\mathrm{Cr}$ and $\mathrm{Ni}$ contents were positively correlated with the comprehensive influence of sediment moisture content, bulk density, TN, and SOC (Figure 2).

\subsection{Spatial Distribution Pattern and Potential Ecological Risk} Assessment of Heavy Metal Pollution. The contents of $\mathrm{Cd}$ and $\mathrm{Pb}$ gradually reduced from the east to west. However, the $\mathrm{Cr}$ and Ni had a patchy distribution pattern in the East Dongting Lake wetlands (Figure 3). Spatial distribution of heavy metals indicated that the individual risk index $\left(E_{r}^{i}\right)$ of heavy metals was ranked in the order of $\mathrm{Cd}>\mathrm{Pb}>\mathrm{Ni}>\mathrm{Cr}$ (Table 4). The individual ecological risk index of $\mathrm{Cd}$ in the East Dongting Lake was 186.37, indicating that $\mathrm{Cd}$ posed a high risk to local ecosystem (Table 4). The integrated Hakanson potential ecological risk index (RI) also showed that the integrated heavy metal pollution in the East Dongting Lake gradually reduced from the east to west (Figure 4).

3.4. Heavy Metal Source. The results were reported as factor loadings of the rotated matrix in Table 5. Two components explained the $84.05 \%$ of the total variance of the total metal concentrations in sediment (Table 5). Cr and Ni were associated with components one (C1), which explained $48.96 \%$ of total variance. $\mathrm{Cd}$ and $\mathrm{Pb}$ were associated with components two (C2), which explained $35.09 \%$ of total variance (Table 5). These results indicated that the source of heavy metal could be divided into two groups: (1) $\mathrm{Cr}$ and $\mathrm{Ni}$ and (2) $\mathrm{Cd}$ and $\mathrm{Pb}$. 
TABLE 3: Pearson's correlation analysis between sediment properties and heavy metal contents $(N=174)$.

\begin{tabular}{|c|c|c|c|c|c|c|c|c|c|c|}
\hline & Moisture & Bulk density & $\mathrm{pH}$ & SOC & TN & $\mathrm{TP}$ & $\mathrm{Cd}$ & $\mathrm{Cr}$ & $\mathrm{Ni}$ & $\mathrm{Pb}$ \\
\hline Moisture & 1 & & & & & & & & & \\
\hline Bulk density & $-.752^{* *}$ & 1 & & & & & & & & \\
\hline $\mathrm{pH}$ & -.062 & $.226^{*}$ & 1 & & & & & & & \\
\hline SOC & $.528^{* *}$ & $-.248^{*}$ & -.096 & 1 & & & & & & \\
\hline $\mathrm{TN}$ & $.544^{* *}$ & $-.294^{* *}$ & $-.271^{* *}$ & $.945^{* *}$ & 1 & & & & & \\
\hline $\mathrm{TP}$ & .055 & -.026 & .161 & -.104 & -.169 & 1 & & & & \\
\hline $\mathrm{Cd}$ & .001 & $-.259^{*}$ & $-.354^{* *}$ & -.181 & -.127 & -.033 & 1 & & & \\
\hline $\mathrm{Cr}$ & .178 & -.185 & -.143 & $.249^{* *}$ & $.285^{* *}$ & .024 & .100 & 1 & & \\
\hline $\mathrm{Ni}$ & $.358^{* *}$ & -.196 & -.140 & $.347^{* *}$ & $.408^{* *}$ & -.095 & .026 & $.749^{* *}$ & 1 & \\
\hline $\mathrm{Pb}$ & -.014 & -.195 & $-.459^{* *}$ & -.164 & -.076 & -.103 & $.593^{* *}$ & .095 & .140 & 1 \\
\hline
\end{tabular}

${ }^{*} P<0.05 ;{ }^{* *} P<0.01$ (two tailed).

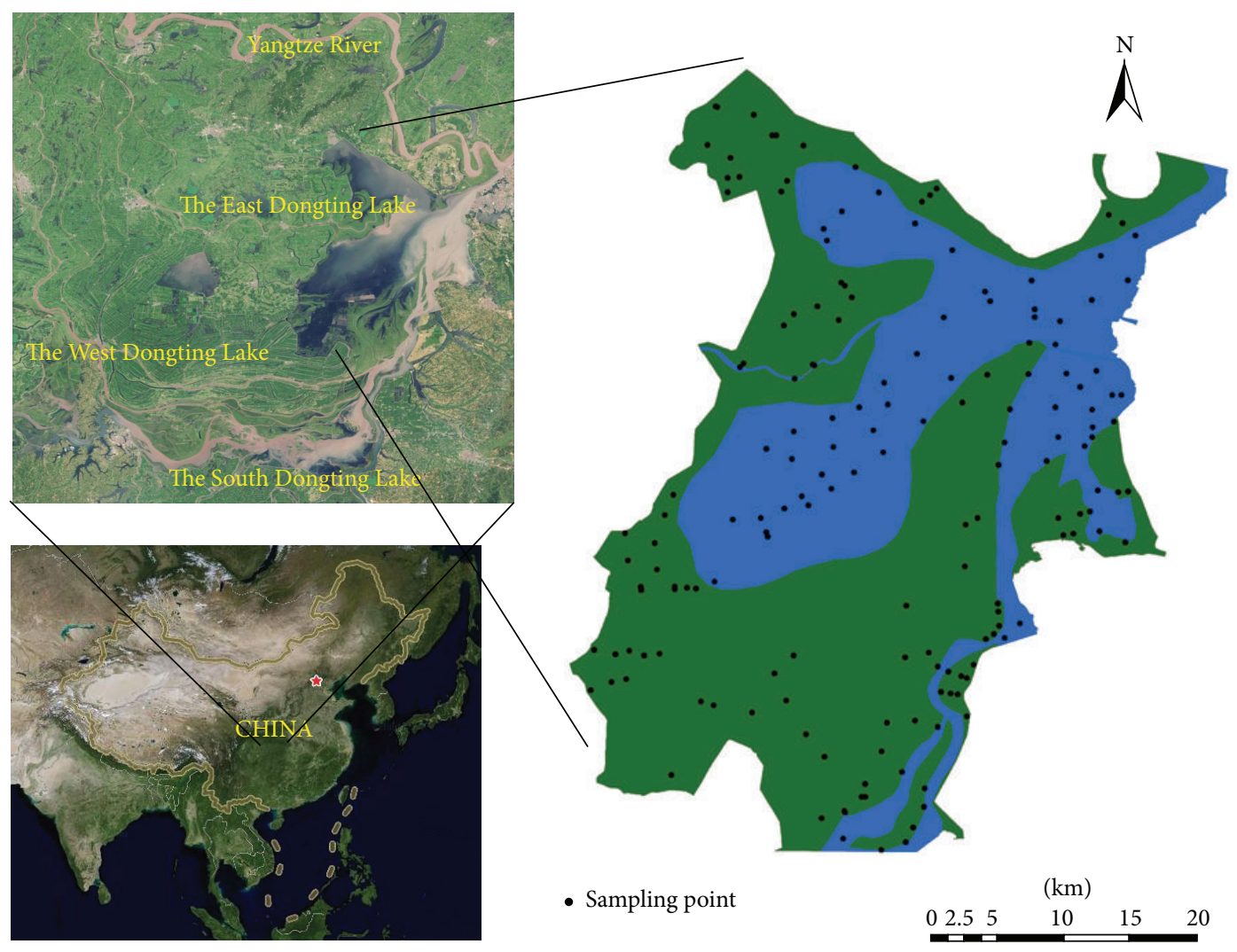

FIGURE 1: Map of sediment samples collecting locations in the East Dongting Lake wetlands.

TABLE 4: Heavy metal toxic coefficient and geochemistry background of the Dongting Lake wetlands.

\begin{tabular}{lcccc}
\hline Items & $\mathrm{Cd}$ & $\mathrm{Cr}$ & $\mathrm{Ni}$ & $\mathrm{Pb}$ \\
\hline $\begin{array}{l}\text { Toxic coefficient }\left(T_{r}^{i}\right) \\
\text { Reference dose } \\
\left(C_{R}^{i}\right)\left(\mathrm{mg} \mathrm{kg}^{-1}\right)\end{array}$ & 30 & 2 & 5 & 5 \\
$\begin{array}{l}\text { The single risk } \\
\text { indices }\left(E_{r}^{i}\right)\end{array}$ & 1.74 & 108.25 & 46.17 & 41.32 \\
\hline
\end{tabular}

\section{Discussion}

The mean value of the studied heavy metals $(\mathrm{Cd}, \mathrm{Cr}, \mathrm{Ni}$, and $\mathrm{Pb}$ ) in surface sediment exceeded the geochemistry background value of Dongting Lake, and the content of Cd exceeded almost eight-fold of the geochemistry background value of Dongting Lake (Table 2). These results indicated that the heavy metal pollution, especially for Cd pollution, in the East Dongting Lake was apparent. Other studies have 
TABLE 5: Total variance explained and rotated component matrix (two principal components selected) for heavy metal contents in the sediments from the East Dongting Lake wetlands. Factor loadings exceeding 0.5 are expressed in bold font.

\begin{tabular}{lcccccc}
\hline Component & \multicolumn{3}{c}{$\begin{array}{c}\text { Initial eigenvalues } \\
\text { \% of variance }\end{array}$} & Cumulative \% & Component matrixes & \multicolumn{2}{c}{ Rotated component matrix } \\
& Total & 48.960 & 48.960 & $\mathrm{Cd}$ & -0.034 \\
\hline 1 & 1.958 & 35.089 & 84.049 & $\mathrm{Cr}$ & $\mathbf{0 . 9 0 7}$ \\
2 & 1.414 & 10.240 & 94.289 & $\mathrm{Ni}$ & 0.923 \\
4 & 0.410 & 5.711 & 100 & $\mathrm{~Pb}$ & $\mathbf{0 . 9 3 4}$ & 0.066 \\
4 & 0.228 & & & & $\mathbf{0 . 8 7 7}$ \\
\hline
\end{tabular}

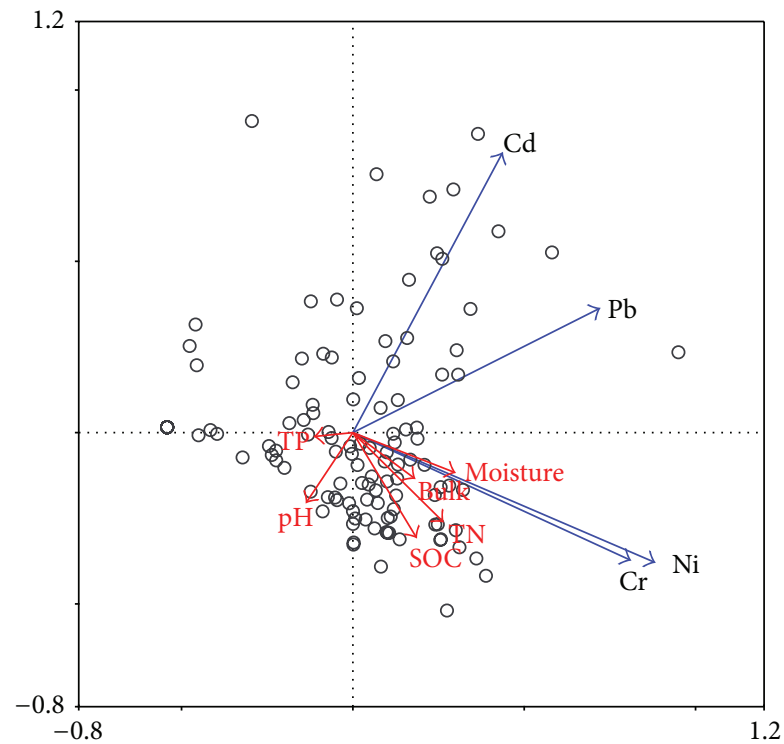

FIGURE 2: Ordination plots of the primary component analysis (PCA) of the metal concentrations of sediment. The direction of an arrow indicates the steepest increase in the variable, and the length indicates the strength relative to other variables. TP, total phosphorus; TN, total nitrogen; SOC, sediment organic carbon; Bulk, bulk density; Moisture, sediment moisture content.

also reported that there was a serious Cd pollution in the Dongting Lake sediment $[15,24,25]$, but the pollution degree varied significantly in different areas. The average content of $\mathrm{Cd}$ in the South Dongting Lake was $3.05 \mathrm{mg} \mathrm{kg}^{-1}$ [24] and that in the East Dongting Lake was $0.98 \mathrm{mg} \mathrm{kg}^{-1}$ in 2009 (ranged from 0.21 to $4.79 \mathrm{mg} \mathrm{kg}^{-1}$ ) [25]. However, we found that the mean value of $\mathrm{Cd}$ content in the East Dongting Lake was $1.71 \mathrm{mg} \mathrm{kg}^{-1}$ (ranged from 0.55 to $5.26 \mathrm{mg} \mathrm{kg}^{-1}$ ). These differences may be caused by the different sampling areas and the variations between years [26]. The content of $\mathrm{Cr}, \mathrm{Pb}$, and $\mathrm{Ni}$ was between class I and class II of the national standards, indicating the sediment of the East Dongting Lake was also suffering $\mathrm{Cr}, \mathrm{Pb}$, and $\mathrm{Ni}$ pollution.

Correlation analysis showed that $\mathrm{Cd}$ and $\mathrm{Pb}$ contents were negatively related to $\mathrm{pH}$, while $\mathrm{Cr}$ and $\mathrm{Ni}$ contents were positively related to soil organic carbon (SOC) and total nitrogen (TN). Another study has reported that the metal sorption mechanism could be greatly affected by solution $\mathrm{pH}$, because $\mathrm{Cd}$ and $\mathrm{Pb}$ could be fixed as $\mathrm{CdCO}_{3}, \mathrm{Cd}(\mathrm{OH})_{2}$, or $\mathrm{Pb}_{3}\left(\mathrm{CO}_{3}\right)_{2}(\mathrm{OH})_{2}$ under alkaline conditions [27]. Fourest and Roux (1992) have also observed inhibition of chelation when the $\mathrm{pH}$ decreased during the heavy metal adsorption process in Rhizopus arrhizus [28]. However, there was usually a reducing environment with relatively lower $\mathrm{pH}$ in the sediment of lakes (Table 1), which may also inhibit the fixation of heavy metals. Additionally, the higher organic carbon (SOC) and total nitrogen (TN) content (Table 1) caused by the decomposition of vegetation could act as a sink for the heavy metals and in turn increased the content of heavy metal in the sediment of the East Dongting Lake [2]. What is more, the longer submergence time combined with higher water level may also result in the large number of heavy metal deposition in the east of the East Dongting Lake wetlands [29].

The potential risk assessment of heavy metal pollution demonstrated that the East Dongting Lake has been suffering serious heavy metal pollution, especially for Cd. The area adjacent to Xiangjiang River was the most contaminate part for $\mathrm{Cd}$ and $\mathrm{Pb}$ (Figures 3 and 4), indicating that the main source of $\mathrm{Cd}$ and $\mathrm{Pb}$ may originate from Xiangjiang River, due to industrial, agricultural, municipal, and residential waste water discharging $[15,25]$. However, $\mathrm{Cr}$ and $\mathrm{Ni}$ had a patchy distribution pattern and the ecological risk was relatively lower (Table 4), indicating that the main source of $\mathrm{Cr}$ and $\mathrm{Ni}$ might derive from parent material weathering [15].

\section{Conclusions}

Results obtained in this study showed that $\mathrm{Cd}$ had the highest mean value, followed by $\mathrm{Pb}, \mathrm{Ni}$, and $\mathrm{Cr}$ in surface sediment in the East Dongting Lake wetland. $\mathrm{Cd}$ and $\mathrm{Pb}$ contents were negatively related to $\mathrm{pH}$, while $\mathrm{Cr}$ and $\mathrm{Ni}$ contents were positively related to soil organic carbon (SOC) and total nitrogen (TN). Therefore, to reduce the risk of heavy metal pollution in the East Dongting Lake wetland, we should do much more efforts to control the industrial waste water discharging, and reasonably adjusting the water $\mathrm{pH}$ and nutrition (i.e., SOC and TN) might be another effective way to alleviate the risk of heavy metal pollution in the East Dongting Lake wetland.

\section{Conflict of Interests}

The authors declare that there is no conflict of interests regarding the publication of this paper. 

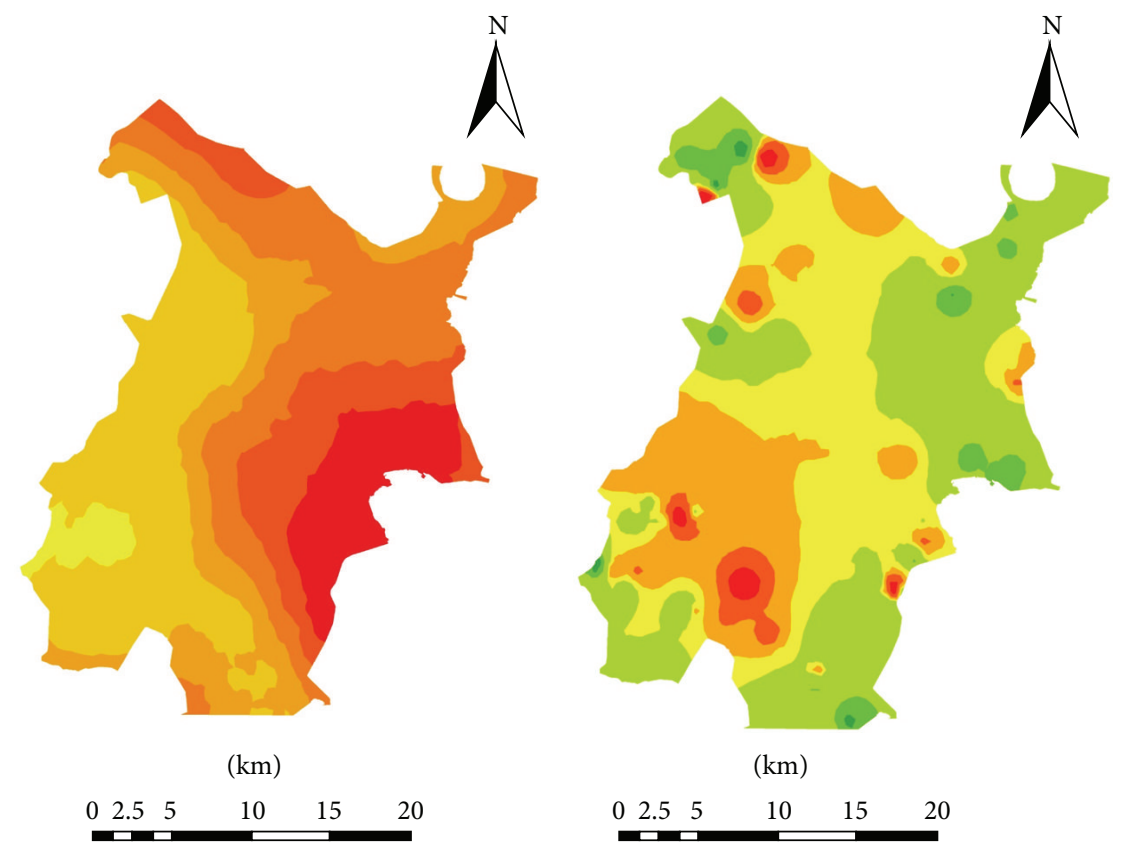

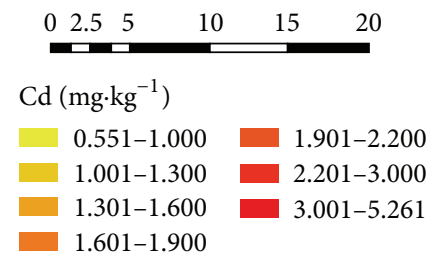

(a)

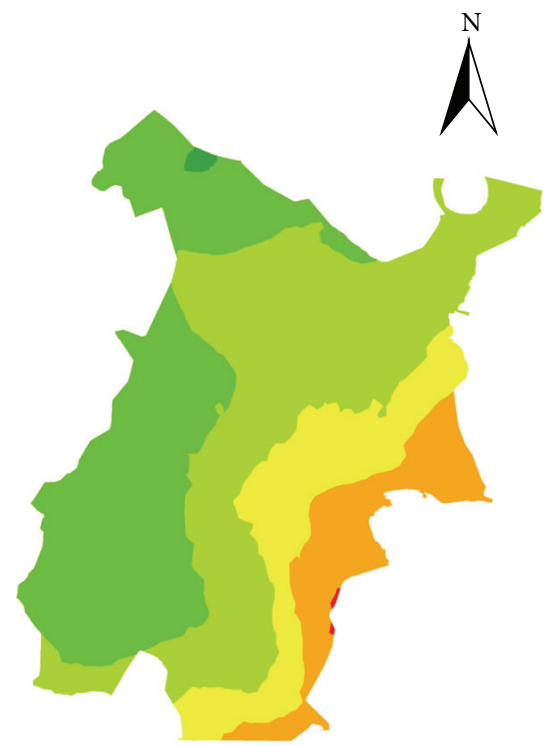

$(\mathrm{km})$

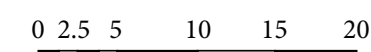

$\mathrm{Pb}\left(\mathrm{mg} \cdot \mathrm{kg}^{-1}\right)$

- 12.419-25.000 55.001-65.000

25.001-35.000 65.001-75.000

35.001-45.000 75.001-97.895

45.001-55.000

(c)

$$
\begin{array}{lr}
\mathrm{Cr}\left(\mathrm{mg} \cdot \mathrm{kg}^{-1}\right) & \\
66.158-90.000 & 120.001-130.000 \\
90.001-100.000 & 130.001-140.000 \\
100.001-110.000 & 140.001-178.859 \\
110.001-120.000 &
\end{array}
$$

(b)

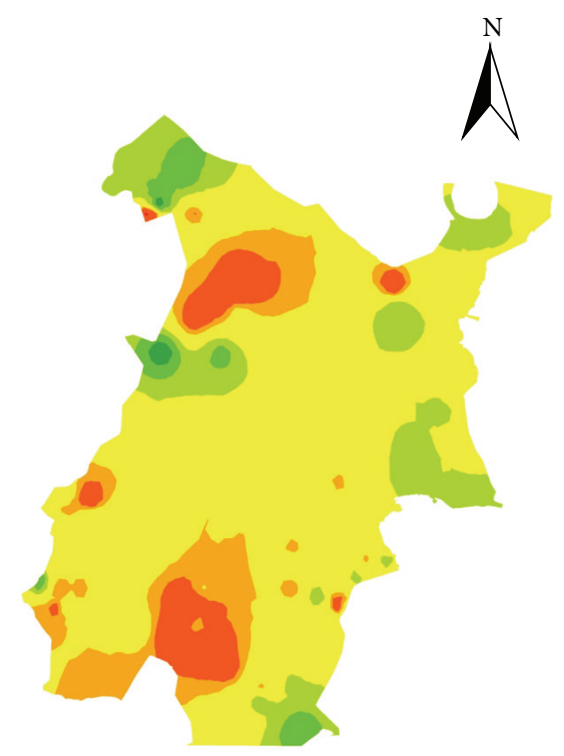

$(\mathrm{km})$

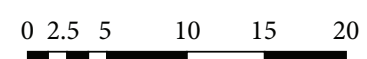

$$
\begin{array}{rr}
\mathrm{Ni}\left(\mathrm{mg} \cdot \mathrm{kg}^{-1}\right) & \\
24.638-35.000 & 50.001-55.000 \\
35.001-40.000 & 55.001-60.000 \\
40.001-45.000 & 60.001-65.714 \\
45.001-50.000 &
\end{array}
$$

(d)

FIgURe 3: Spatial distribution of $\mathrm{Cd}(\mathrm{a}), \mathrm{Cr}(\mathrm{b}), \mathrm{Pb}(\mathrm{c})$, and $\mathrm{Ni}(\mathrm{d})$ concentrations in the East Dongting Lake wetlands. 


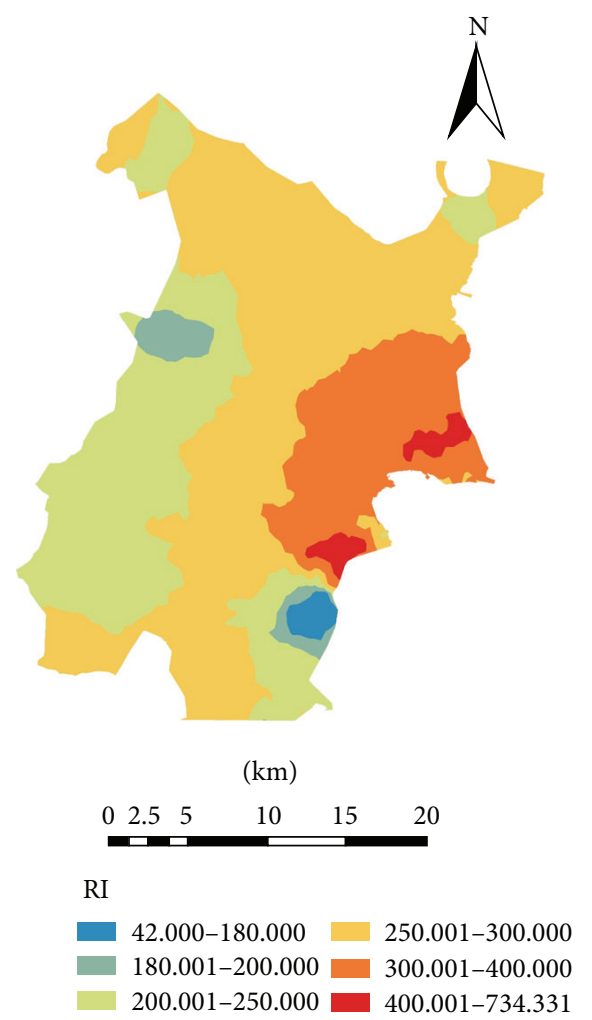

FIGURE 4: Spatial distribution of integrated potential ecological risk index (RI) for the studied heavy metals in the East Dongting Lake wetlands.

\section{Acknowledgments}

The authors greatly appreciate three anonymous reviewers for their constructive comments on the paper. The authors also greatly appreciate Li Jiang, Yue Tang, Na Liu, and Tina Zheng for offering help in designing graphs and reviewing language. This study was supported by the National Key Research and Development Program of China (2014BAC09B03), the National Basic Investigation Fund (2013FY111800), and National Natural Science Foundation of China (41401290).

\section{References}

[1] C. Zhang, E. X. Appel, and Q. Q. Qiao, "Heavy metal pollution in farmland irrigated with river water near a steel plantmagnetic and geochemical signature," Geophysical Journal International, vol. 192, no. 3, pp. 963-974, 2013.

[2] J. Bai, R. Xiao, K. Zhang, and H. Gao, "Arsenic and heavy metal pollution in wetland soils from tidal freshwater and salt marshes before and after the flow-sediment regulation regime in the Yellow River Delta, China," Journal of Hydrology, vol. 450-451, pp. 244-253, 2012.

[3] O. O. Ayeni, P. A. Ndakidemi, R. G. Snyman, and J. P. Odendaal, "Chemical, biological and physiological indicators of metal pollution in wetlands," Scientific Research and Essays, vol. 5, no. 15, pp. 1938-1949, 2010.

[4] V. K. Gaur, S. K. Gupta, S. D. Pandey, K. Gopal, and V. Misra, "Distribution of heavy metals in sediment and water of river
Gomti," Environmental Monitoring and Assessment, vol. 102, no. 1-3, pp. 419-433, 2005.

[5] B. Cui, Q. Zhang, K. Zhang, X. Liu, and H. Zhang, "Analyzing trophic transfer of heavy metals for food webs in the newlyformed wetlands of the Yellow River Delta, China," Environmental Pollution, vol. 159, no. 5, pp. 1297-1306, 2011.

[6] S. N. Sin, H. Chua, W. Lo, and L. M. Ng, "Assessment of heavy metal cations in sediments of Shing Mun River, Hong Kong," Environment International, vol. 26, no. 5-6, pp. 297-301, 2001.

[7] E. Álvarez, M. L. Fernández Marcos, C. Vaamonde, and M. J. Fernández-Sanjurjo, "Heavy metals in the dump of an abandoned mine in Galicia (NW Spain) and in the spontaneously occurring vegetation," Science of the Total Environment, vol. 313, no. 1-3, pp. 185-197, 2003.

[8] F. Zeng, S. Ali, H. Zhang et al., "The influence of $\mathrm{pH}$ and organic matter content in paddy soil on heavy metal availability and their uptake by rice plants," Environmental Pollution, vol. 159, no. 1, pp. 84-91, 2011.

[9] J. Kumpiene, A. Lagerkvist, and C. Maurice, "Stabilization of As, $\mathrm{Cr}, \mathrm{Cu}, \mathrm{Pb}$ and $\mathrm{Zn}$ in soil using amendments-a review," Waste Management, vol. 28, no. 1, pp. 215-225, 2008.

[10] G. Du Laing, B. Vandecasteele, X. van Doorslaer, and F. Tack, "Efficiency of selenium uptake from a Belgian soil treated with a commercial se-containing fertilizer by grass and maize," in Selenium Deficiency Toxicity and Biofortification for Human Health, 2009.

[11] F. Thevenon, N. D. Graham, M. Chiaradia, P. Arpagaus, W. Wildi, and J. Poté, "Local to regional scale industrial heavy metal pollution recorded in sediments of large freshwater lakes in central Europe (lakes Geneva and Lucerne) over the last centuries," Science of the Total Environment, vol. 412-413, pp. 239-247, 2011.

[12] X. Ding and X. Li, "Monitoring of the water-area variations of Lake Dongting in China with ENVISAT ASAR images," International Journal of Applied Earth Observation and Geoinformation, vol. 13, no. 6, pp. 894-901, 2011.

[13] Z.-H. Guo, J. Song, X.-Y. Xiao, H. Ming, X.-F. Miao, and F.-Y. Wang, "Spatial distribution and environmental characterization of sediment-associated metals from middle-downstream of Xiangjiang River, Southern China," Journal of Central South University of Technology, vol. 17, no. 1, pp. 68-78, 2010.

[14] L. Chai, Z. Wang, Y. Wang, Z. Yang, H. Wang, and X. Wu, "Ingestion risks of metals in groundwater based on TIN model and dose-response assessment-a case study in the Xiangjiang watershed, central-south China," Science of the Total Environment, vol. 408, no. 16, pp. 3118-3124, 2010.

[15] F. Li, J. Huang, G. Zeng et al., "Integrated source apportionment, screening risk assessment, and risk mapping of heavy metals in surface sediments: a case study of the dongting lake, middle China," Human and Ecological Risk Assessment, vol. 20, no. 5, pp. 1213-1230, 2014.

[16] M. R. Carter and E. G. Gregorich, Soil Sampling and Methods of Analysis, Canadian Society of Soil Science, 2nd edition, 2006.

[17] J. Bai, R. Xiao, B. Cui et al., "Assessment of heavy metal pollution in wetland soils from the young and old reclaimed regions in the Pearl River Estuary, South China," Environmental Pollution, vol. 159, no. 3, pp. 817-824, 2011.

[18] J. Bai, Z. Yang, B. Cui, H. Gao, and Q. Ding, "Some heavy metals distribution in wetland soils under different land use types along a typical plateau lake, China," Soil and Tillage Research, vol. 106, no. 2, pp. 344-348, 2010. 
[19] D. Nelson, L. Sommers, A. Page et al., Methods of Soil Analysis: Chemical and Microbiological Properties, American Society of Agronomy, Madison, Wis, USA, 1983.

[20] M. Saeedi, L. Y. Li, and M. Salmanzadeh, "Heavy metals and polycyclic aromatic hydrocarbons: pollution and ecological risk assessment in street dust of Tehran," Journal of Hazardous Materials, vol. 227-228, pp. 9-17, 2012.

[21] L. Hakanson, "An ecological risk index for aquatic pollution control. A sedimentological approach," Water Research, vol. 14, no. 8, pp. 975-1001, 1980.

[22] H. Yongming, D. Peixuan, C. Junji, and E. S. Posmentier, "Multivariate analysis of heavy metal contamination in urban dusts of Xian, Central China," Science of the Total Environment, vol. 355, no. 1-3, pp. 176-186, 2006.

[23] C. Micó, L. Recatalá, M. Peris, and J. Sánchez, "Assessing heavy metal sources in agricultural soils of an European Mediterranean area by multivariate analysis," Chemosphere, vol. 65, no. 5, pp. 863-872, 2006.

[24] M. Dong, Y.-L. Zhao, W.-Z. Ku, R.-R. Tuo, M.-B. Dai, and H.C. Yi, "Cadmium enrichment characteristics of eight dominant plant species in dongting lake wetland," Chinese Journal of Ecology, vol. 30, no. 12, pp. 2783-2789, 2011.

[25] H. Wang, Spatial distribution and risk assessment of heavy metals in Eastern Dongting Lake Wetland [M.S. thesis], Hunan Normal University, 2012.

[26] J. Liang, J. Liu, X. Yuan et al., "Spatial and temporal variation of heavy metal risk and source in sediments of Dongting Lake wetland, mid-south China," Journal of Environmental Science and Health, Part A, vol. 50, no. 1, pp. 100-108, 2015.

[27] X. Chen, J. V. Wright, J. L. Conca, and L. M. Peurrung, "Effects of $\mathrm{pH}$ on heavy metal sorption on mineral apatite," Environmental Science and Technology, vol. 31, no. 3, pp. 624-631, 1997.

[28] E. Fourest and J. C. Roux, "Heavy metal biosorption by fungal mycelial by-products: mechanisms and influence of $\mathrm{pH}$," Applied Microbiology and Biotechnology, vol. 37, no. 3, pp. 399403, 1992.

[29] L. Wang, Y.-P. Wang, C.-X. Xu, and Z.-Y. An, "Pollution characteristics and ecological risk assessment of heavy metals in the surface sediments of the Yangtze River," Environmental Science, vol. 33, no. 8, pp. 2599-2606, 2012. 

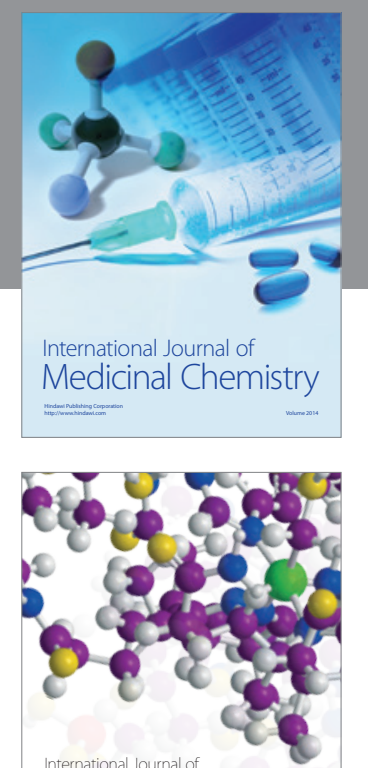

\section{Carbohydrate} Chemistry

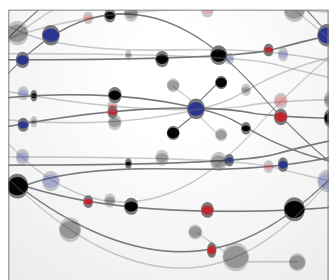

The Scientific World Journal
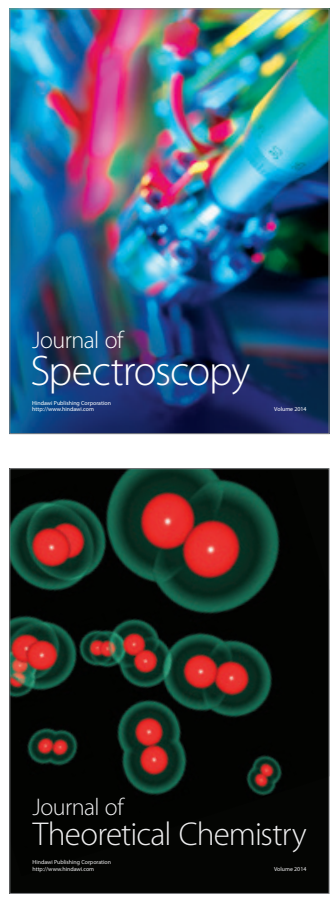
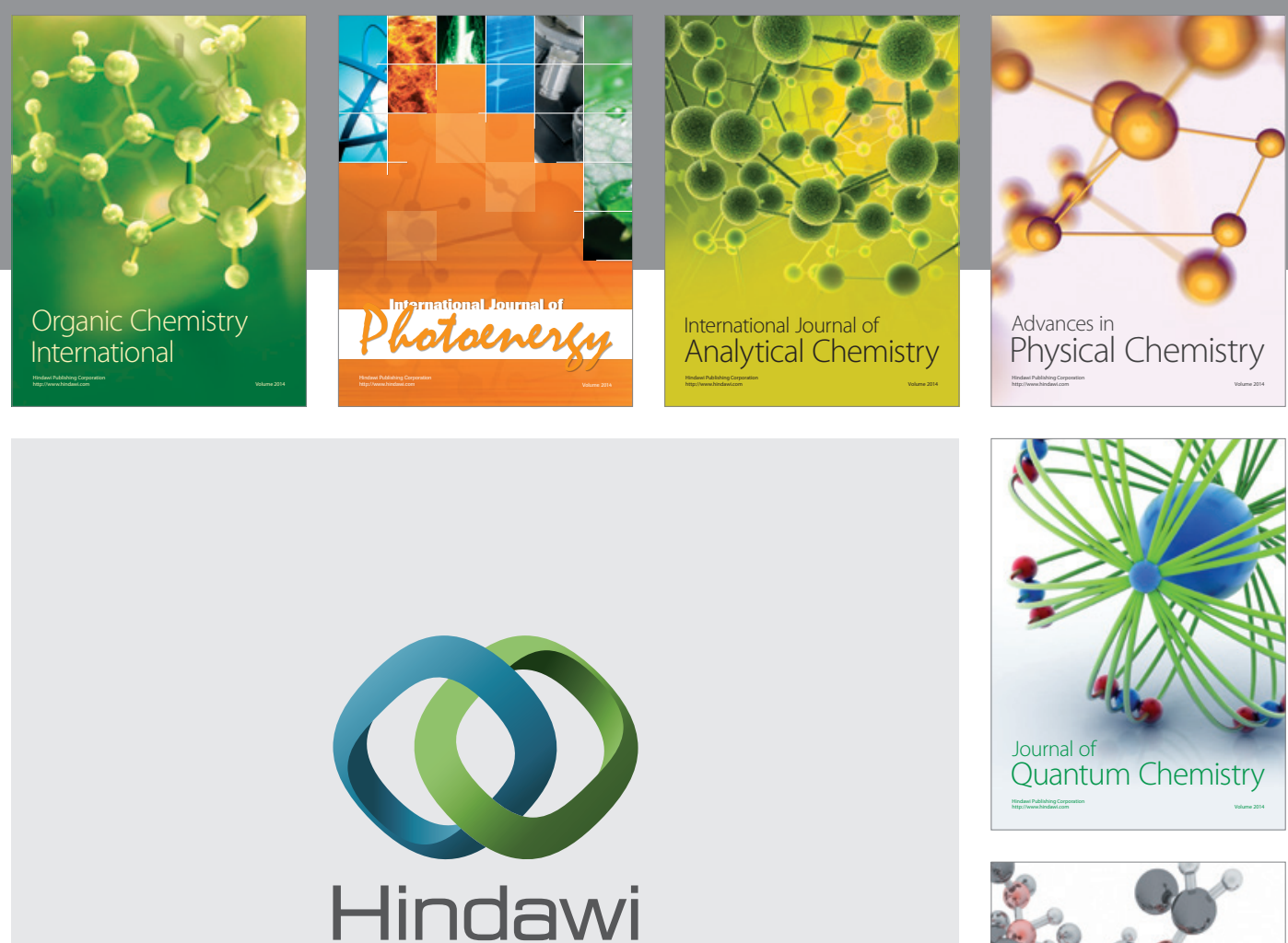

Submit your manuscripts at

http://www.hindawi.com

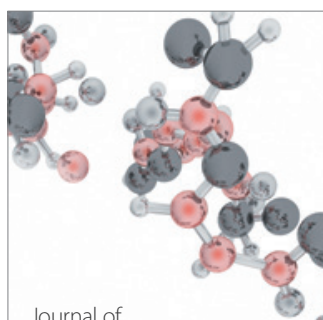

Analytical Methods

in Chemistry

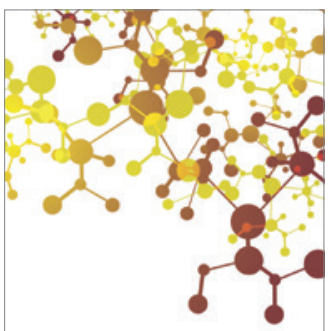

Journal of

Applied Chemistry

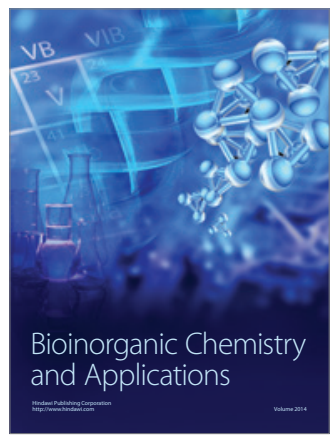

Inorganic Chemistry
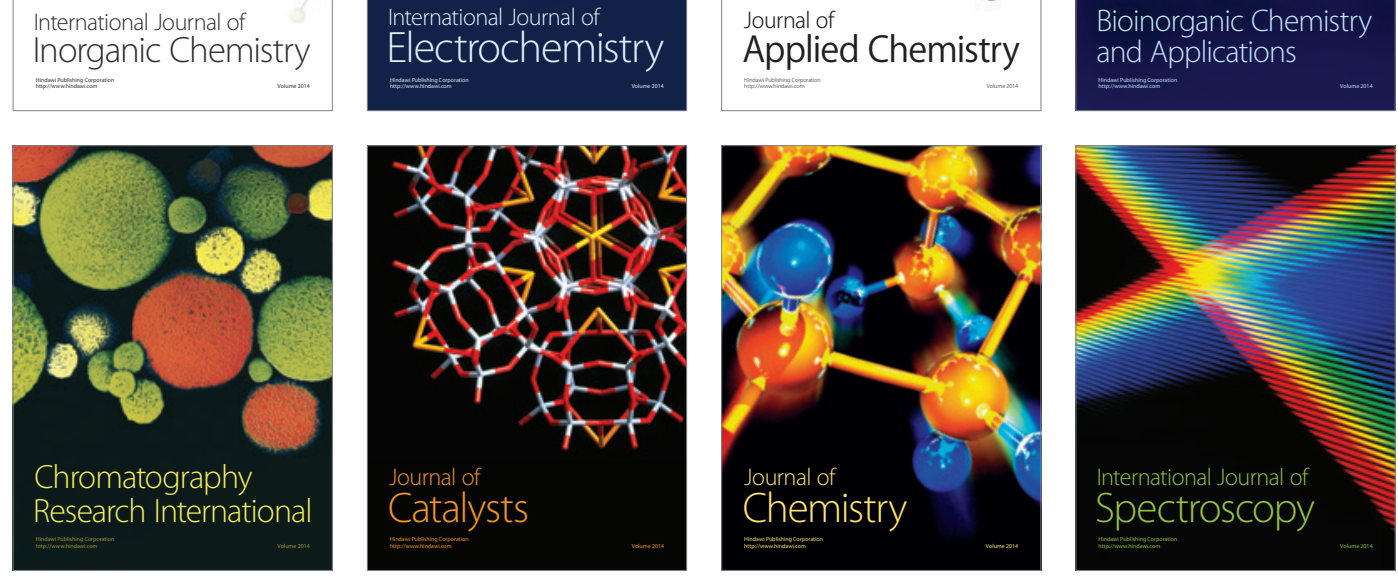